\title{
WestVirginiaUniversity.
}

Department of Economics

Working Paper Series

\section{Visigothic Retinues: Roving \\ Bandits that Succeeded Rome}

Andrew T. Young

Working Paper No. 15-09

This paper can be found at the College of Business and Economics

Working Paper Series homepage: 


\title{
Visigothic Retinues: \\ Roving Bandits that Succeeded Rome ${ }^{\dagger}$
}

\author{
Andrew T. Young \\ College of Business and Economics \\ West Virginia University \\ Morgantown, WV 26506-6025 \\ ph: 3042934526 \\ em: Andrew.Young@mail.wvu.edu
}

Latest Version: May 2015

\begin{abstract}
I employ a case study of the Visigoths in the fourth and fifth centuries to analyze the collective action problems faced by roving versus stationary bandits. A roving bandit provides exclusive collective goods to its members. A stationary bandit also provides exclusive goods to its members, but it also provides inclusive collective goods to out-group individuals in its domain. The inclusive goods provided to the out-group are an input to the production of the exclusive goods enjoyed by the in-group members. I describe how the transition from the former to the latter likely involves redefinition of the relevant group, its shared interest, and the type of $\operatorname{good}(\mathrm{s})$ that it provides. The Gothic retinues of the fourth century were essentially roving bandits. Having been driven across the Danube into the Roman Empire by an invasion of Huns, a group of these retinues formed the Visigothic confederacy. The Visigoths sacked Rome and were subsequently settled in Gaul, eventually becoming the stationary Visigothic Kingdom. I describe how the Visigothic elite came to recognize an encompassing interest in their domain and drew upon the human capital of the Gallo-Roman senators to provide inclusive collective goods.
\end{abstract}

JEL Codes: D72, N43, N93, P16,

Keywords: collective action problems, governance institutions, state emergence, roving versus stationary bandits, Visigoths, Roman Empire, ancient economic history

${ }^{\dagger}$ I thank the participants at a 2015 Center for Free Enterprise brown-bag for their comments and discussion regarding the ideas that came to constitute this paper. Keith Dougherty and other participants at the 2015 Public Choice Society meetings provided insightful criticisms and discussion. I have also benefited from discussions with Bryan McCannon about the issues discussed within. 
It seems that at first he ardently desired to blot out the Roman name and to make all the Roman territory a Gothic empire in fact as well as in name, so that, to use the popular expressions, Gothia should take the place of Romania, and he, Athaulf, should become all that Caesar Augustus had once been.

Orosius (Seven Books of History Against the Pagans, Book 7, p. 396)

\section{Introduction}

Olson (1993, p. 567) characterizes anarchy in terms of "uncoordinated competitive theft by 'roving bandits"'. The emergence of government out of anarchy involves a "stationary bandit" that monopolizes theft and achieves an encompassing interest in some domain. The stationary bandit to provides public goods, such as law and order, to increase the wealth base from which it extracts. As long as total wealth increases by more than the amount extracted, both the bandit and the people in its domain are made better off by this movement out of anarchy.

The collective action problems that must be solved by such "bandits", both roving and stationary, are lurking in the background of Olson's (1993) analysis. In this context a bandit cannot be interpreted to mean a single individual. Monopolization of theft over a domain large enough to be termed a "state" requires the organization and coordination of a large group of individuals. An Olsonian bandit, therefore, must be interpreted as an effective theft-oriented organization pursuing the shared interests of its group members. Organizations that solve collective action problems to further group interests are the focus Olson's (1971 [1965]) classic, The Logic of Collective Action. In this paper I provide provide an Olsonian (1971) analysis of Olsonian (1993) bandits. To illustrate some of the relevant problems in group definition and 
collective action, I will employ a case study of the fourth and fifth century Visigothic migrations and the subsequent establishment of the Visigothic Kingdom in Gaul and the Iberian Peninsula.

The sort of theft-oriented organization described by Olson (1993) must be effective both initially as a roving bandit and subsequently as a stationary bandit or state. Being an effective roving bandit will not necessarily imply being effective once stationary. The organization may have to transform itself. In particular, it may have to (1) redefine its group to both (2) recognize an encompassing interest in some domain and then (3) effectively pursue it by providing collective goods. The redefinition of the group may involve the inclusion of new members and the exclusion of some existing members. Furthermore, there may be changes in the types of collective goods that organization provides.

Scholars possess scant historical knowledge of actual roving bandits that became stationary. The processes by which erstwhile roving bandits redefined their groups and shared interests played out in largely prehistoric times. To empirically illustrate these processes we must rely on evidence of societies that straddle the prehistoric and the historic, either temporally or spatially in the sense they are observed by other, historic societies. Kurrild-Klitgaard and Svendsen (2003) and Baker and Bulte (2010) are examples of such investigations that focus on Vikings from around $800 \mathrm{AD}$ to $1100 \mathrm{AD}$. Baker and Bulte advance the conjecture that competitive agglomeration of Viking groups, as well as of the groups defending against their attacks, played an important role in state formation. Kurrild-Klitgaard and Svendsen provide a "theoretical history" (p. 256) of how some Viking groups transitioned from roving to stationary bandits. For most of the period considered by these authors, the Vikings did not keep their own written records. Yet their raiding groups may have been playing out an institutional evolution towards becoming states. 
Alternatively, in a previous paper (Young, 2015) I study much earlier European societies of Germanic barbarians. I document the institutional changes in Germanic governance institutions that occurred from the first century BC through the first century AD. One notable change was the transition from temporary military kings elected from the nobility to standing armed retinues led by entrepreneurial commanders. These armed retinues were essentially Olsonian roving bandits: "If not governments, they were governance organizations with selfenforcing constitutions; a meaningful step out of the state of nature for these barbarians" (Young, 2015, p. 24). In that paper I allude to these retinues as precursors to the stationary barbarian kingdoms that succeeded the Western Roman Empire. While I elaborate in some detail on the collective action problems faced and solved by these retinues, my characterization of them as precursors to the successor kingdoms was just a lick and a promise. In this paper I follow up with a more thoroughgoing defense of that characterization.

The illustrative historical case study that I employ involves a later (fourth and fifth century) group of Germanic barbarians: the Visigoths. During most of the fourth century, armed retinues similar to those described in Young (2015) were characteristic of Visigothic society. During times of emergency (e.g., war) these retinues would occasionally confederate under an over-commander (referred to as a judge). But these confederacies would disband once the emergency had passed. Visigothic society during most of the fourth century is best characterized as one of roving bandits.

Alternatively, one particularly enduring confederacy was settled in the province of Gallia Aquitania around 417 by the Roman general (later emperor) Constantius III. By that time, I argue, many of this confederacy's rank and file warriors were becoming cognizant of a breakdown of shared interest with the Visigothic elite. Likewise, the Visigothic elites were 
beginning to recognize encompassing interest in their domain. In particular, the barbarians were settled under the Roman policy of hospitalitas. Under this policy the Visigothic elites were granted broad claims to productive land shares. Furthermore, the elites stood to gain from exploiting the bureaucratic human capital of the Gallo-Roman aristocracy. Providing law and order required administration and taxation of the domain, something with which the barbarians had little experience. Alternatively, the senatorial class was literate and constituted the Empire's bureaucracy and civil service. Throughout the rest of the fifth century a true Visigothic Kingdom was established, with a capital in Toulouse, which by 476 (the conventional dating of the Western Empire's "fall") came to control southern Gaul and most of the Iberian Peninsula.

I provide a brief overview of Visigothic history from the fourth through the fifth centuries $\mathrm{AD}$ in section 2. Then, in section 3, I review my earlier account of the first century Germanic retinues (Young, 2015) and argue that similar retinues characterized fourth century Visigothic society. I provide an analysis of how a confederacy of these retinues evolved into the stationary Visigothic Kingdom in section 4. Concluding discussion is found in section 5.

\section{The Visigoths: A Brief History from Constantine to their Settlement in Aquitaine}

The Goths were a collection of eastern Germanic tribes. Based largely on the sixth century historian Jordanes, scholars were once comfortable speaking of two distinct Gothic tribes: the Visigoths (or Tervingi) and the Ostrogoths (Greuthungi). It was believed that these groups were well-defined going back to at least the third century. However, most scholars now believe that Gothic tribal/political affiliations were more fluid, and that the distinct Visigothic identity did not emerge until after a large group of Goths, fleeing an invasion by the Huns in 376, crossed the Danube and were settled in Moesia by the emperor Valens. Indeed, the Visigothic identity may 
not have emerged until the confederacy of Alaric formed in 395 (e.g., Collins, 2004, pp. 17-26;

Grierson, 1941, pp. 11-14; Heather, 1996, pp.130-151). Below I refer to the Goths in reference to events prior Alaric's confederacy; then the Visigoths in reference to subsequent events.

Up through Diocletian there is little recorded of the Goths, and even during the first part of Constantine's rule literary sources mention only occasional raids on the Roman provinces of Thrace and Moesia around the lower Danube (an area that included parts of Bulgaria, Greece, Macedonia, Serbia, and Turkey). The historical record of Gothic activity falls temporarily silent after a devastating campaign by Constantine north of the Danube in $332 .{ }^{1}$ Then, during the reigns of the brothers Valentinian and Valens, Goths were again raiding in Thrace and Moesia (Ammianus, Book 26, p. 322).

The brother emperors attempted to discourage such raids by granting the Goths (or at least some groups of Goths) status as federates (foederati) of the Empire. Federates were granted annual subsidies (monetary; grain; clothing) in exchange for their non-aggression and defense the frontier against other barbarian groups. However, the leading men (principatus) of these federate Goths mistakenly sent 3,000 warriors in support of a usurper named Procopious (Ammianus, Book 26, p. 332). ${ }^{2}$ (Apparently the Goths were not savvy in distinguishing legitimate Roman emperors from usurpers!) After Procopious was defeated, Valens (367-369) prohibited trade with the Goths and undertook three years of campaigns across the Danube. Valens defeated the Goths, who had confederated under a judge (iudicem) named Athanaric. The

\footnotetext{
${ }^{1}$ In 323 Constantine campaigned against Gothic raiders in Thrace and Moesia. In 324 Gothic warriors led by a prince (regalis) named Alica fought against Constantine on the side of the co-emperor Licinius in the Battle of Chrysopolis. Constantine won and subsequently (circa 332) responded to a request for aid from the Sarmatians, a group of Iranian-speaking barbarians who were being harassed by a Gothic army. That winter Constantine crossed the Danube and crushed the Gothic army, reducing them to a state of famine (Anonymous Valesianus, Ch. 5, pp. 525-529).

${ }^{2}$ In addition to the translation of Ammianus Marcellinus listed in the references, I have referenced the original Latin provided by http://www.thelatinlibrary.com/ammianus.html. I refer to the Latin, in particular, when various terms that imply subtly different things (e.g., reges, duces, and principes) are often translated into one English word (e.g., "kings").
} 
Goths begged for peace and the Romans obliged. Famously, Valens and Athanaric concluded a treaty while afloat on the Danube - an arrangement allegedly made so the Athanaric could obey his father's command to never to set foot upon Roman soil (Ammianus, Book 27, pp. 336-337). ${ }^{3}$

Soon afterwards: "The race of the Huns, long shut off by inaccessible mountains, broke out in sudden rage against the Goths and drove them in widespread confusion from their old homes" (Orosius, Book 7, p. 373). This "savage horde of remote tribes" had swept into the region north of the lower Danube from the Asian Steppe and over the Black Sea, "driven from their homes by some unexpected pressure” (Ammianus, Book 31, p. 416). In 376 as many as 1 million Goths gathered on the northern bank of the Danube, requesting permission to enter the Empire. Valens was in Antioch (modern day south-central Turkey) and his military forces were preoccupied with conflicts on the Persian frontier. Being in no position to actually prevent the Goths' migration across the frontier, Valens "permitted" their entry. Under the leadership of two judges, Fritigern and Alavius, these Goths were settled in Thrace. ${ }^{4}$

Two corrupt Roman generals, Lupicinius and Maximus, mismanaged the settlement of the Goths. Rather than providing them with food subsidies as federates of the Empire (as promised by Valens), they "collected all the dogs that their insatiable greed could find and

\footnotetext{
${ }^{3}$ The standard translation involves Athanaric having sworn an oath never to set foot on Roman soil. Interestingly then, having been defeated by the Huns and his leadership abandoned by his Goths, Athanaric was later received by Theodosius I in Constantinople, where the erstwhile judge died. Wolfram (1975, p. 263) points out that the correct interpretation of the Latin is actually: "the Gothic chief was bound by an especially severe oath and that a paternal order had forbidden him to set foot on Roman soil." If he did not break and oath, then, the passage begs the question of what exactly this sever oath was!

${ }^{4}$ As Ammianus (Book 31, pp. 416-417) dryly observes: "[T] he affair seemed matter for rejoicing rather than dread, and the practised flatterers in the emperor's entourage extolled in exaggerated terms the good fortune which unexpectedly presented him with a large body of recruits drawn from the ends of the earth. [...] With these high hopes [...] the greatest care was taken to ensure that [...] none of those destined to overthrow the Roman Empire should be left behind." Orosius (Book 7, p. 373) is more concise: the Goths were "received by Valens without negotiating any treaty. They did not even surrender their arms to the Romans." Athanaric, having proved unsuccessful in his efforts to ward off the Huns, was disgraced and abandoned by most of his followers and remained north of the Danube. Later on, during Theodosius I's reign, Athanaric reappears (in disobedience to his father's command) within the Roman Empire. He was invited to Constantinople by Theodosius in 381 and, a few weeks later, was dead.
} 
exchanged each of them for a slave, and among these slaves were some sons of the leading men [optimatum]" (Ammianus, Book 31, p. 418). Subsequently, Fritigern led the Goths south to Marcianople to plead their case to Roman authorities. Upon their arrival, Lupicinus invited Fritigern and other Gothic leading men to a feast at which several of them were killed or taken hostage. Fritigern escaped and led a Gothic confederacy that routed Lupicinus' troops in Marcianople. What followed was the Gothic War of 376-382, punctuated by the defeat (and death) of Valens at the Battle of Adrianople in 378. The massacre of two thirds of Valens army was the most stunning defeat that Rome had ever suffered at the hands of northern barbarians.

The emperors Gratian (who succeeded in the West in 375 when Valentinian died) and Theodosius (who was elevated to the purple in the East in 379) picked up where Valens had left off, but with more success. However, the Goths were formidable enough to bring Theodosius to the negotiating table. In 382 a treaty was signed, the conditions of which testify to Rome's inability to defeat the barbarian confederation outright. In a departure from precedent, the Goths were not only granted land to settle; they were also allowed to maintain their own laws and communal autonomy. In return, as federates the Goths probably agreed to provide military services, including recruits, to Rome (Heather, 1998, p. 137). At this point we lose track of Fritigern and no new judge is named by the literary sources for the remainder of Theodosius' rule. Its usefulness having passed, the confederacy apparently disbanded.

By some accounts, Theodosius exhibited marked diplomacy towards the Goths. He regularly extended invitations to Gothic leading men to dine with him (Enapius fr. 59). However, he also called upon his federates to campaign against two separate usurpers (Maximus, who had murdered Gratian, and then Eugenius; both in the West). A Gothic revolt followed the campaign against Maximus but amounted to little. However, in the campaign against Eugenius there were 
reportedly as many as 10,000 Gothic casualties..$^{5}$ Theodosius died in 395 , leaving his sons, Honorius (about 8 years old) in the West and Arcadius (about 12 years old) in the East, as coemperors. The Goths took advantage of the disturbance in Roman authority to confederate under the leadership of the judge Alaric.

Alaric appears to have played a role in the campaign against Eugenius (Zosimus, Book 5, p. 133) and from this he may have become familiar with northwest Italy. He invaded Italy in 401 but was driven back by Stilicho, Honorius' magister militum. A second invasion followed and also ended in defeat, but Alaric was able to extort increased subsidies in exchange for remaining peacefully in Illyricum (the province bordering Italy in the northeast and running down along the Adriatic Sea). Whether this peaceful settlement would have endured, we will never know. Members of Honorius' court came to suspect Stilicho, himself of barbarian (Vandal) stock, of conspiring with Alaric. ${ }^{6}$ Stilicho was removed by a coup and fled to Ravenna where he was captured and executed in 408. In the aftermath, Roman soldiers "hearing of the death of Stilico [sic] fell upon the women and children in the city, who belonged to the Barbarians[;] destroyed every individual of them [and] plundered them of all they possessed" (Zosimus, Book 5, p. 161). As a result, Zosimus reports that Alaric's Visigothic confederacy swelled by 30,000 new recruits. The Visigoths invaded Italy once more and this time they besieged the Eternal City itself in 410. "By all accounts, there followed one of the most civilized sacks of a city every witnessed," states Heather (2006, p. 227). After three days there had been relatively little destruction to buildings and monuments. The Christian Visigoths treated holy places with particular respect and let them be used as sanctuaries during the sack. Alaric's plan was to

\footnotetext{
${ }^{5}$ Orosius (Book 7, p. 380) counts this a double victory for the Empire: "for the loss of these [the Gothic auxiliaries] was certainly a gain and their [the usurper and his followers] defeat a victory." The Gothic leading men may have found the federate status more beneficial than the Gothic rank and file, a point to which I will return to in section 4 below.

${ }^{6}$ This was probably not true, but Stilicho had strongly supported granting the larger subsidies to the Visigoths in exchange for peaceful settlement in Illyricum.
} 
subsequently march south and cross into Africa, but it was not to be. The first Visigothic judge died before he could cross the Mediterranean Sea.

The Visigothic confederacy did not disband following Alaric's death. His brother-in-law, Athaulf, succeeded him as judge. Notably, during the sack of Rome the sister of Honorius, Galla Placida, was captured and Athaulf took her as his wife. Orosius (Book 7, p. 390) claims that this was a boon to the Empire's relations with the Visigoths: it was "as if she had been a hostage given by Rome as a special pledge[;] through her alliance with the powerful barbarian king, Pacidia did much to benefit the state."

In the meantime, a usurper out of Britain, Constantine III, had declared himself emperor in the West in 407. Constantine III was defeated in 411 by Honorius' magister militum, Contantius. However, no sooner had he been defeated than another usurper, Jovinus, claimed the purple in the Rhineland. This all provided an effective distraction for Athaulf who, in 412, led the Visigoths out of Italy and into Gaul. ${ }^{7}$ The Visigothic judge attempted to negotiate some sort of federate status with Jovinus, but it seems that the latter was partial towards another Gothic (but not Visigothic) commander named Sarus. Athaulf eschewed diplomacy and the Visigoths attacked Sarus and his followers, defeating them and killing him. Jovinus then elevated his brother Sebastian to share the purple, which apparently further aggravated Athaulf who felt that he should have been consulted. The Visigoths then aligned themselves with Honorius and defeated Jovinus (who was subsequently beheaded) in 413.

At this point the Visigoths temporarily claimed Toulouse and Narbonne. However, their relationship with Honorius became strained and the patrician Constantius (later the emperor Constantius III) was ordered to blockade Gaul's Mediterranean naval ports. The blockades were

\footnotetext{
${ }^{7}$ This was much to the chagrin of Honorius who, "seeing that nothing could be done against the barbarians when so many usurpers were opposed to him, ordered that the usurpers themselves should be destroyed" (Orosius, Book 7, p. 393).
} 
successful and caused Athaulf to lead the Visigoths into the northern Iberian Peninsula. In 415 Athaulf met his end by treachery in Barcelona at the hands of one of his own men. In his wake, a man named Segeric claimed the command of the confederacy. Apparently he did so without broad Visigothic support because he was killed within a week. The Visigoths then chose Wallia to lead them. Orosius claims that "Wallia succeeded to the kingdom, having been chosen by the Goths to break the peace, but appointed by God to establish it" (Book 7, p. 396). A less charitable view is that the Gothic rank and file found themselves on the wrong side of an agency problem. Given the anti-Roman sentiment, Wallia considered marching south and invading Africa. But he apparently thought better of it and sought out a peace with the Empire. He returned Galla Placidia to Honorius. The emperor reciprocated by settling the Visigoths as federates in Aquitaine (western Gaul south of the Loire) around 417. Wallia established a capital in Toulouse and, under his leadership, the Visigoths carried out various campaigns in the Iberian Peninsula against the Vandals, Sueves, and Alans, as well as a usurper named Maximus.

Theoderic I succeeded Wallia in 419. Whereas there is no compelling evidence that Alaric, Athaulf, Segeric, and Wallia were blood relatives, Theoderic established a dynasty that would last for over a century. The Visigothic Kingdom had been established.

\section{Retinues: Roving Barbarian Bandits}

Gaius Cornelius Tacitus published the Germania towards the end of the first century (circa 98 AD). In it, Tacitus records details of the barbarian peoples and their societies from the vast area that roughly encompassed modern Germany, Denmark, Poland, Slovakia, the Czech Republic, half of Hungary, and a part of Austria. ${ }^{8}$ Many believe that Tacitus' account is based largely on

\footnotetext{
${ }^{8}$ Archeological finds indicate that southern Norway and Sweden can also be included in the sense that Germanic peoples were present (Todd, 1987, p. 1).
} 
the Elder Pliny's lost work, Bella Germaniae, and that Tacitus never actually set foot in Germania (Gudeman, 1900). If this is true, then the Germania is probably based on observations between 50 and $54 \mathrm{AD}$.

In one of the Germania's most famous lines, Tacitus states that the Germans "choose their kings [reges] for their noble birth, their commanders [duces] for their valour" (ch. 7, p. 107). ${ }^{9}$ The military commanders that Tacitus describes are very different that those on which Julius Caesar commented in his Commentarii de Bello Gallico (Gallic War), written subsequent to conquest of Gaul (58-50 BC). ${ }^{10}$ During Caesar's time, Germanic military commanders were chosen from royal (or at least noble) families; only during times of emergency, and only for the duration of the emergency. However, Tacitus describes military commanders whose standing retinues provided protection services and also pursued profit-seeking raids. In regards to the latter, they very much resembled the roving bandits described by Olson (1993).

In Caesar's earlier account the kings (reges) are nobility, and they are associated with the sacral. Alternatively, the commanders (duces) of Tacitus' account are violent formeteurs (Congleton, 2011) who organized warriors into armed retinues that functioned as profit-seeking organizations. That profit was through "war and plunder" (Tacitus, ch. 14, p. 113). Furthermore, these retinues operated in a competitive marketplace: "there [was] great rivalry, both among the followers to obtain the highest place in their leader's estimation and among the chiefs for the honour of having the biggest and most valiant retinue" (Tactitus, ch. 13, p. 112). While the warriors were motivated to obtain the highest place in their leader's estimation, earning that place was associated with more tangible rewards (ch. 14, p. 113):

\footnotetext{
${ }^{9}$ References to the Germania text will generally be from the 1970 Penguin edition; I use the 1869 Macmillan and Co. edition to reference the original Latin for certain words.

${ }^{10}$ In Young (2015) I explore Caesar's observations on Germanic governance in detail, and also contrast those observations with those of Tacitus in detail. Both in that paper and here my references to the Gallic War are from the 1939 edition translated by Edwards and including the Latin.
} 
[A] large body of retainers cannot be kept together except by means of violence and war. They are always making demands on the generosity of their chief, [...]. Their meals [...] count in lieu of pay. The wherewithal for this openhandedness comes from war and plunder.

Commanders had to compete for the best warriors, and if those warriors were not remunerated accordingly then they could turn to competing duces that would do so.

These retinues were organized as clubs with self-enforcing constitutions (Leeson, 2011). ${ }^{11}$ A commander (qua formeteur) organized a group of warriors and then (qua entrepreneur) identified profit opportunities and provided leadership in their pursuit. The warriors were residual claimants of the retinue's profits (in the form of a commander's largesse). The profits, of course, depended on the warriors collectively following the commander's lead and not shirking during battle. The oath-bound warriors likely policed one another through the threat of physical violence on defectors. Furthermore, Tactitus remarks that to "throw away one's shield in battle is the supreme disgrace, and the man who has thus dishonoured himself is debarred from attendance at sacrifice or assembly" (Tacitus, ch. 6, pp. 106-107). This suggests across Germanic society broadly there existed mechanisms that contributed to an individual retinue's constitution being self-enforcing. Shirking may have led to exclusion from religious and governance institutions. ${ }^{12}$

The available evidence suggests that armed retinues of the type described by Tacitus in the first century were still prevalent in Germanic societies generally, and Gothic societies in particular, during the fourth century. Roman historians took greater notice of the confederacies

\footnotetext{
${ }^{11}$ Club theory is associated with the seminal work of Buchanan (1965). Sandler and Tschirhart (1997) provide a review of the subsequent contributions.

${ }^{12}$ Religious clubs often rely on the threat of stigmatization and requirements of sacrifice to identify and exclude potential defectors (e.g., Berman and Laitin (2008) and Iannaccone (1992)).
} 
that from time to time. But that is not surprising given the motivations of those historians. ${ }^{13}$ Even in 376, when the Visigoths were gathering on the banks of the Danube to plead for admission to the Empire, Ammianus Marcellinus (Book 31, p. 416) notes: "Our people paid little attention to this at first, because news of wars in those parts generally reaches distant hearers only when they are already over or at least quiescent." Romans were generally unconcerned with the internal matters of barbarians and tended to take notice only when larger confederacies involved themselves in the affairs of the Empire.

Between confederacies, the literary sources become relatively quiet. But what they do offer is consistent with the existence and activity of numerous armed retinues. In particular, the sources report occasional, small-scale raids across the frontier into Roman provinces.

Furthermore, emperors appear to have dealt with these small-scale raids in ways that suggest that they did not interpret them as orchestrated by some centralized state. For example, Gothic raids into Thrace and Moesia did not typically provoke an overwhelming response from Rome. Anonymous Valesianus (ch. 5, p. 523) refers simply to Constantine's “check of their attack”. And even during the period when Valentinian and Valens had granted federate status to some group of Goths, sporadic Gothic raids into Thrace and Moesia did not provoke a strong response. As Thompson (2008 [1966], pp. 13-14) notes, "these bands [of raiding Goths] seem to have been local or tribal levies, retinues of Gothic optimates[;] not sent out by the central authority [...] and their activities, though of course illegal, were not inconsistent with the Federate status of the Visigoths as a whole."

\footnotetext{
${ }^{13}$ Caesar and Tacitus are the only two Romans to bother recording observations of Germanic barbarians with an eye towards the details of their societal and political structures (a fact which I exploit in Young (2015)). Romans' interest was generally limited to barbarian developments that directly impacted the Empire: wars and their outcomes; the recruitment of barbarians into the Roman army their loyalty or lack thereof; barbarian migrations across the frontier.
} 
Alternatively, when a larger army of Goths (presumably a confederation) attacked a group of Sarmatians with federate status in 323, Constantine's son Constantius (II; later coemperor) came to the defense of the Sarmatians. Contantius' winter campaign resulted in "almost a hundred thousand of the Goths [...] destroyed by hunger and cold" (Anonymous Valesianus, ch. 6, p. 528). While this contemporary source (circa 390) may be exaggerating the number, there is no doubt that Constantius attacked and crushed a well-defined enemy. Similarly, when 3,000 Goths (presumably a confederacy) joined in support of the usurper Procopious, Valens followed up on his defeat with three years (367-369) of campaigning across the Danube. This campaigning led to Valen's defeat of “Athanaric, at that time [the Goth's] most powerful ruler [iudicem; judge]" and "reduced the barbarians to such want that they sent a number of delegations to beg for pardon and peace" (Ammianus, Book 27, p. 337). The use of iudicem implies an over-commander; "a chief with powers superior to those of other chiefs" (Thompson, 2008 [1966], p. 45). ${ }^{14}$

The evidence suggests, then, that large confederations of Goths were not the norm. Rather they were short-lived organizations that were motivated by specific episodes or war or other emergency. Smaller-scale armed retinues of the type described by Tacitus were the norm.

\section{Towards a Stationary Visigothic Kingdom}

Up through the fourth century a Visigothic retinue resembled what Olson (1971, pp. 36-43) referred to as an exclusive group, meaning that it provided an exclusive collective good(s) to its group members. An exclusive collective good is one that is rivalrously enjoyed by group

\footnotetext{
14 The reference to delegations also suggests that Valens was dealing with a Gothic confederation. This is also supported by Ammianus' (Book 27, p. 332) statement that the initial 3,000 Goths supporting Procopious were sent by "their kings, now reconciled to Rome[.]" The plural indicates that it was, again, a confederacy of retinues - the same one that had been granted federate status - that was for a specific purpose united under an elected judge.
} 
members and also difficult to exclude individual members from enjoying. Because it is rivalrous the amount enjoyed per member is decreasing in the number of members. A critical problem in groups providing exclusive goods is the regulation of the consumption by individual members. ${ }^{15}$

A roving bandit provides an exclusive collective good to its members: plunder. A key conundrum facing the commander of a roving bandit is how to prevent some members from shirking and freeriding off of the efforts of others. The results of raiding are, for the most part, likely to be divided equally. The plunder is not purely nonexcludable within the group. (For example, a member who has been detected while obviously shirking can be denied his share. Also, an elite amongst the group may command larger shares.) However, accurately observing individual relative efforts during a raid and then dividing up shares of plunder accordingly is likely to be prohibitively costly. A commander as formeteur must limit group membership to regulate the consumption per capita of a given amount of plunder; as entrepreneur he also has to manage the members so that all are pulling their weight.

Consider the Visigothic retinues of the fourth century. The provinces of Thrace and Moesia had a combined population of only about 2.5 million. Diminishing returns to additional warriors would have set in at fairly small retinue sizes. Beyond the number of warriors necessary to "efficiently" plunder a village or other population center, additional warriors would have drawn down the plunder per capita more than they added to it. Heather (1998, p. 66) notes: "the rise of groups of specialist armed retainers was a social development of the greatest importance. $[\ldots]$ In the bulk of so-called Free Germany $[\ldots]$ weapon burials became common from at least the

\footnotetext{
${ }^{15}$ Olson uses the example of a cartel working to establish an above-competitive price for its members' output. Given demand for that particular output, the more firms in the cartel the less each member can sell; the lower each member's profits. Furthermore, if the cartel cannot restrict individual firms from over-consuming the abovecompetitive price (i.e., putting too much output on the market for sale) then the exclusive good cannot be provided effectively.
} 
first century AD." These burials as well as literary sources suggest that retinues of 200 or so men were the norm (Heather, 1998, pp. 66-68).

For an organization such as the Visigothic retinue to transition from roving to stationary bandit, at least two fundamental changes may have to occur. First, the scale of the organization must increase significantly. A group of 200 warriors cannot monopolize a domain large enough to be considered a state (especially given fourth and fifth century military technologies). Second, the organization has to provide inclusive collective goods such as law and order. A supply of inclusive collective goods automatically expands as the number of individuals in the domain (and hence the theft/tax base) increases. Inclusive goods are both nonrival and nonexcludable they are what economists typically mean in reference to public goods. ${ }^{16}$

For Olson (1993), a stationary bandit is a state (or at least a proto-state). However, thinking in terms of exclusive versus inclusive collective goods provision may provide a useful distinction between the two. A stationary bandit is a group that, like a roving bandit, provides an exclusive good to its members (plunder - now called taxes). However, it also provides inclusive goods (e.g., law and order) to out-group members. The incentive to provide inclusive goods exists because they are an input to the production of the exclusive collective good that group members enjoy. The inclusive goods increase the tax base from which the group extracts. Alternatively, most would consider a state to be a group containing all a domain's people. The government of a state provides inclusive goods to the group members. A stationary bandit recognizes an encompassing interest in its domain because doing so furthers its special interest.

\footnotetext{
${ }^{16}$ A given supply of law and order can be subject to overcrowding/congestion, decreasing the quality and quantity provided per capita. In this sense it is not a pure public good. (See Comes and Sandler (1996) and Sandler (2013) for helpful discussions of impurely public goods.) This distinction is of second-order importance for the present discussion but if, for example, Gallo-Roman labor was an imperfect substitute for Visigothic warriors in the provision of coercion or the threat thereof, then it could have had implications for the size of the Visigothic Kingdom, at least in the short-run
} 
Alternatively, a state recognizes an encompassing interest because its domain encompasses all of its members.

Returning to the discussion of Gothic retinues, an increase in scale occurred periodically when a number of them confederated, most often to defend against or attack similarly large groups of Romans or other barbarian groups. These confederations were typically short-lived. However, under the leadership of Alaric a Visigothic confederation formed in 395 that endured and was eventually settled in Gaul under the leadership of Athaulf in 418/419. This confederation proved more durable in part because the Visigoths benefited from federate status. Furthermore, Alaric's sack of Rome gave the Visigoths not only a taste of plunder writ large, but also greater bargaining power for imperial subsidies. As Collins (2004, p. 22) observes:

[T] he so-called Visigothic confederacy in the Balkans after the treaty of 381 was a permanent military force in service of the emperor and was generally supplied by the imperial administration or was permitted to requisition the civilian population.

Collins characterizes the Visigothic confederacy as a mercenary army, providing services in exchange for subsidies. However, it can also be interpreted succeeding in an act of extortion: the Visigoths were being paid to not wreak havoc. The confederacy was still a roving bandit, but one that realized some economies of scale in going after bigger game. ${ }^{17}$

A fundamental transformation then occurred between Alaric's confederation and the nascent Visigothic kingdom of Theoderic. As Diaz (1999, p. 329) observes: "the figure of Alaric

\footnotetext{
${ }^{17}$ Baker and Bulte (2010) describe the agglomeration of smaller Viking groups. Kurrild-Klitgaard and Svendsen (2003, p. 261) provide further detail that is reminiscent of the Visigothic experience: "Raiding Vikings began to band together in large fleets and armies [and] sacked towns and markets[....] Occasionally the forces disbanded, while at other times they re-united in the so-called 'Great Army."' Apparently Viking small-scale roving bandits also (at least initially) periodically took part in short-lived confederations. Interestingly, the theory that KurrildKlitgaard and Svendsen (2003) provide to account for the Viking experience does not explicitly deal with the process of confederation.
} 
can still be explained according to the model of a military chief at the head of a semi-nomadic group, something like a soldier of fortune at the head of a professional army [...] fed by his capacity to satisfy the demands of his followers.” Alternatively, as indicated by Orosius' attribution, "Athaulf looked more decisively for new patterns of power[;] land for permanent settlement and a territorialized power that was symbolically and formally capable of being assimilated to Roman patterns of power[.]”

The Visigothic Kingdom of the mid-fifth through eight centuries realized an encompassing interest in its domain. It taxed and provided defense of the realm; law and order within it. These inclusive goods created a surplus that was divided in a mutually beneficial way between the Visigoths and their subjects. Heather (1998, p. 183) observes that:

Fifth-century Aquitaine was extremely prosperous, in so far as prosperity can be measured by artistic production for its elite[....] This elite prosperity must reflect at least the general conditions created by the Visigothic settlement[.] Furthermore: "The evidence for taxation paints, I think, a similar picture. Salvian, a priest of Marseilles, described at great length how, because of their tax burdens, rich and poor Romans alike had fled to the Goths" (Heather, 1998, p. 185).

While the Gallo-Romans appear to have recognized the net benefits associated with their barbarian overlords, this is not to say that they necessarily embraced them or were embraced by them. The Gallo-Romans were generally out-group members:

The barbarians, after all, might prove not more objectionable than the [imperial] officials, by turns negligent and extortionate[....] This, perhaps, accounts for the curious double theme of Aquitanian Christian literature: on the 
one hand, the Goths were welcomed as saviours from the Romans, and on the other attacked for their ruthless treatment [...] (Wallace-Hadrill, 1967, p. 29). The early Visigothic Kingdom was clearly a stationary bandit; it provided inclusive collective goods to the domain at large but only because it benefited the Visigoths.

While Gallo-Romans were generally out-group, the Visigothic elite (leading men; optimates) was beginning to embrace at least part of their aristocracy. And this redefinition of the stationary bandit was not welcomed by all of the existing members. The Visigothic elite was in a position to negotiate their settlement with the Empire. This also put them in a position to administer Roman subsidies. Furthermore, settlement under the hospitalitas system gave the Visgothic elite an encompassing interest in the domain that was independent of the fate of the Empire.

Under the hospitalitas system, barbarians were legally treated as Roman soldiers being settled in a territory for the purpose of its defense. They were allotted a share of the productive land (often quoted as two thirds of the arable and one half of the pasture). Hospitalitas would have been administered through the Visigothic elite. The Visigothic elite gained "skin in the game"; claims on long-lived productive assets across the domain. ${ }^{18}$ This served to create an encompassing interest in the domain for the Visigothic elite; to align their incentives with individuals of the domain at large (McGuire and Olson, 1996). ${ }^{19}$ They recognized an encompassing interest because doing so became consistent with their special interest.

\footnotetext{
${ }^{18}$ Alternatively, Goffart (1980) has argued that the Empire actually provided barbarians with a share of the productive lands revenues (i.e., a tax share). (However, see Heather (1998, p. 182) who argues that the transfer of actual land was at least part of the Visigothic settlement in Aquitaine.) But in the case of taxation, again the Visigothic elite again would administer this and would gain an encompassing interest.

${ }^{19}$ Olson (1993, p. 567) cited a quote from a monarchist in southern Italy (initially quoted in Banfield (1958) as being key motivation for studying the conditions under which both autocracies and democracies are conducive to economic growth: "Monarchy is the best kind of government because the King is then owner of the country." See Polishchuk and Syunyaev (2014) for evidence on the importance of elites' asset ownership for improving the provision of well-defined and enforced property rights. See Blaydes and Chaney (2013) for evidence from medieval
} 
Maximizing the returns on these long-lived assets required the collection of taxes and the provision of inclusive collective goods such as law and order. These would, in addition to violent labor, require a bureaucracy more sophisticated than present in Visigothic political structures. The Visigothic elite turned to the Gallo-Roman aristocracy. Members of the senatorial class had the human capital necessary to provide effective government administration and they factored into Visigothic courts prominently, especially after 450 (Mathisen, 2011; Heather, 1998, 191194). The evolution of the Visigothic Kingdom involved the gradual inclusion of the Roman aristocrats into the relevant group. The prolific Gallo-Roman senator and letter writer, Sidonius Apollinarus, provided a portrayal of the Visigothic King, Theoderic II's (453-466) court that Heather (1998, p. 193) remarks upon:

It portrays a king educated in Roman law and literature, who provided over an ordered court, where unruly behavior, especially drunkenness, was not tolerated. Set against traditional Roman prejudices about 'barbarians', there is no doubt that Sidonius was signaling to his fellow Roman landowners that the Gothic king was a worthy political ally, who had entered the world of Roman civilization.

Implied is the contribution of aristocratic Gallo-Romans to the budding Visigothic legal tradition; also, more generally, the alignment of incentives between the senators and the Visigothic elite. The former also began to dominate ecclesiastical positions. The Church provided an institutional check on the Visigothic government, again helping to align incentives (Mathisen, 2011)).

Europe and the Muslim world supporting the complementary idea that such ownership should align incentives more effective when rulers' tenures are longer. Also, Kurrild-Klitgaard and Svendsen (2003, p. 261 and p. 266) note that Vikings were often granted land by regions where they had or were likely to raid: "it gave the Vikings a long-term personal interest in defending the area and preventing others from attacking it." 
While the Gallo-Roman aristocrats were embraced by the Visigothic elite, evidence suggests that significant parts of the Visigothic rank and file were sensing a divergence of their interests from those of their leading men. Thompson (1982 [1930], p. 48) argues that: "The dominating feature of Visigothic history between the time of Athanaric and that of Wallia is the growing conflict between the interests of [...] the optimates, and those of the rank and file." This is, again, consistent with Osorius' (Book 7, p. 396) attribution to Athaulf that begins this paper:

[A]t first he ardently desired to blot out the Roman name and to make all the Roman territory a Gothic empire in fact as well as in name, so that, to use the popular expressions, Gothia should take the place of Romania, and he, Athaulf, should become all that Caesar Augustus had once been.

Wallia was elected by the Visigoths at large to affect an anti-Roman change in policy stance, but ended up working closely with the Empire to negotiate a settlement and continued military service to the Romans (Orosius, Book 7, p. 396). In general, since the second decade of the fifth century, the Visigoths at large were simply unable to find a leader that would be consistently anti-Roman (Thompson, 2008 [1966]. p. 49).

\section{Concluding Discussion}

Olson (1993) describes anarchy as characterized by roving bandits. When one of these bandits settles down within a particular domain, monopolizes theft, and begins providing public goods, this represents the emergence of a proto-government out of the state of nature. Roving bandits must be interpreted as theft-oriented organizations - a group of individuals organized to pursue a shared interest by extracting the wealth produced by others. What does it take for such and organization to settle down and resemble something more akin to a government? 
In this paper I aim to tentatively address this question. In doing so I bring Olson's (1971 [1965]) perspective to bear on the matter of Olson's (1993) bandits. How groups solve (or fail to solve) the collective action problems that are relevant to them pursuing their collective interests is the focus of Olson's Logic of Collective Action. The collective actions problems faced by roving bandits may be quite different than those faced by their stationary counterparts. The transition from a roving to stationary bandit may involve redefinition of the relevant group as well as the type of good(s) that it provides.

To illustrate these insights I have provided a case study of the fourth and fifth century Visigoths. Armed Gothic retinues of around 200 warriors raided the Roman Empire throughout the fourth century. In the late fourth century, a large and durable Visigothic confederacy under the command of Alaric began raiding on a larger scale, ultimately sacking Rome in 410 . This confederacy was ultimately settled in Gaul in the early fifth century and became the Visigothic Kingdom. How did this happen?

I argue that the larger Gothic confederacies formed during times of emergency or war. They typically disbanded afterwards, since diminishing returns to the number of warriors in a retinue set in quickly given the size of targets to raid. However, imperial subsidies and the experience of sacking Rome gave the Visigothic confederacy a taste for and expectation of rewards to larger scale activities. Furthermore, when the Empire settled the Visigoths in Gaul they granted them large shares of the productive land under the policy of hospitalitas. These grants were administered by the Visigothic elite and gave them an encompassing interest in the domain. To more effectively administer and tax their realm, the Visigothic elite drew upon the human capital of the Gallo-Roman aristocracy. 
We learn a number of things from this analysis and case study. First, there is an important distinction between roving and stationary bandits in terms of the collective goods that they provide. Roving bandits provide an exclusive collective good (plunder) to its group members. While stationary bandits also provide an exclusive good (perhaps now called taxes) to their members, they also provide inclusive collective goods (e.g., law and order) to members of the out-group. Doing so increases the stationary bandit's tax base. One way in which we can conceive of a further step (not considered by Olson) from stationary bandit to a state is the inclusion of the out-group (i.e., the population of the domain generally). 


\section{References}

Ammianus Marcellinus. 1986. The Later Roman Empire (AD 354-378). London, UK: Penguin Books.

Anonymous Valesianus. 1939. Chronica Minora I. Loeb Classical Library. http://penelope.uchicago.edu/Thayer/E/Roman/Texts/Excerpta_Valesiana/home.html.

Baker, M. J., Bulte, E. H. 2010. Kings and Vikings: on the dynamics of competitive agglomeration. Economics of Governance 11, 207-227.

Berman, E., Laitin, D. 2008. Religion, terrorism, and public goods: testing the club model. Journal of Public Economics 98, 1942-1967.

Blaydes, L., Chaney, E. 2013. The feudal revolution and Europe's rise: political divergence of the Christian West and the Muslim world before 1500 CE. American Political Science Review 107, 16-34.

Buchanan, J. M. 1965. An economic theory of clubs. Economica 32, 1-14.

Caesar, J., Edwards, H. J. 1939. The Gallic War. Cambridge, MA: Harvard University Press.

Collins, R. 2004. Visigothic Spain: 409-411. Oxford, UK: Blackwell Publishing.

Congleton, R. D. 2011. Why local government do not maximize profits: on the valueadded by the representative institutions of town and city governance. Public Choice 149, $187-201$.

Cornes, R., Sandler, T. 1996. The Theory of Externalities, Public Goods and Club Goods ( $2^{\text {nd }}$ ed.). Cambridge, UK: Cambridge University Pres.

Diaz, P. C. 1999. Visigothic political institutions. in The Visigoths: From the Migration Period to the Seventh Century (Heather, ed.). Suffolk, UK: Boydell Press. 
Grierson, P. 1941. Election and inheritance in early Germanic kingship. Cambridge Historical Journal 7, 1-22.

Gudeman, A. 1900. The sources of the Germania of Tacitus. Transactions and Proceedings of the American Philological Association 31, 93-111.

Heather, P. 1998. The Goths. Oxford, UK: Blackwell Publishing.

Heather, P. 2006. The Fall of the Roman Empire: A New History of Rome and the Barbarians. Oxford: Oxford University Press.

Iannaconne, L. 1992. Sacrifice and stigma: reducing free riding in cults, communes, and other collectives. Journal of Political Economy 100, 271-91.

Kurrild-Klitgaard, P, Svendsen, G. T. 2003. Rational bandits: plunder, public goods, and the Vikings. Public Choice 117, 255-272.

Leeson, P. T. 2011. Government, clubs, and constitutions. Journal of Economic Behavior and Organization 80, 301-308.

Mathisen, R. 2011. Roman Aristocrats in Barbarian Gaul: Strategies for Survival in an Age of Transition. Austin, TX: University of Texas Press.

McGuire, M. C., Olson, M. 1996. The economics of autocracy and majority rule: the invisible hand and the use of force. Journal of Economic Literature 34, 72-96.

Olson, M. 1971. The Logic of Collective Action: Public Goods and the Theory of Groups. Cambridge, MA: Harvard University Press.

Olson, M. 1993. Dictatorship, democracy, and development. American Political Science Review 87, 567-576.

Orosius, Raymond, I. W. 1936. Seven Books of History against the Pagans: The Apology of Orosius. New York, NY: Columbia University Press. 
Polishchuk, L., Syunaev, G. 2015. Ruling elites' rotation and asset ownership: implications for property rights. Public Choice 162, 159-182.

Sandler, T. 2013. Public goods and regional cooperation for development: a new look. Integration \& Trade Journal 36, 13-24.

Sandler, T., Tschirhart, J. 1997. Club theory: thirty years later. Public Choice 93, $335-355$.

Tacitus, G. C., Church, A. J., Brodribb, W. J. 1869. The Germania of Tacitus. London and Cambridge: Macmillan and Co.

Tacitus, G. C., Mattingly, H., Handford, S. A. 1970. The Agricola and the Germania. London, UK: Penguin Books.

Thompson, E. A. 1982. Romans and Barbarians: The Decline of the Western Empire. Madison, WI: University of Wisconsin Press.

Thompson, E. A. 2008. The Visigoths in the Time of Ulfila. London, UK: Duckworth and Co. Todd, M. 1987. The Northern Barbarians: 100 BC - AD 300. Oxford, UK: Basil Blackwell.

Wallace-Hadrill, J. M. 1967. The Barbarian West: 400-1000. London, UK: Hutchinson an Co. Wolfram, H. 1975. Athanaric the Visigoth: monarchy or judgeship. A study in comparative history. Journal of Medieval History 1, 259-278.

Young, A. T. 2015. From Caesar to Tacitus: changes in early Germanic governance circa 50 BC-50 AD. SSRN Working Paper. http://papers.ssrn.com/sol3/papers.cfm?abstract_id=2521212.

Zosimus. 1814. New History. London, UK: Green and Chaplin. 